Length 4.3-4.9 mm., width 0.8-0.9 mm. Habitat, Bolivia.

Head transverse; front feebly convex, shining, densely, finely, shallowly punctulate, the punctures becoming microscopically ocellated and more densely placed posteriorly and laterally. Pronotum seven-eighths as wide as long, widest at the prominent anterior angles, five-sixths as wide at base, surface transversely convex, finely punctate, median line impunctate. Scutellum large, twice as wide as long, one-fifth as wide as elytra, surface shining with transverse postmedian elevated line and posterior marginal stria. Elytra as wide as pronotum at anterior angles, three times as long as wide, shining,punctate-striate, intervals impunctate, apices separately rounded. Male with last sternite longitudinally broadly concave and strongly tumid at sides near apex, hind femora armed with tooth at middle of upper carina of inner edge: female with depressed and elevated areas of last sternite more feeble.

Type, allotype, and one paratype No. 26488 , U. S. N. M.

Described from a male and two females collected with scale insects in hollow swellings at fork of twigs of Cordia alliodora Ruiz and Pavon (probably var. boliviana Chodat and Vischer) near Huachi, on the Rio Beni, approximately latitude $15^{\circ} 40$ south longitude $67^{\circ} 20^{\prime}$ west.

\title{
II. A NEW MICRODON FROM PANAMA.
}

By Wm. M. ManN,

National Zoological Park, Washington, D. C.

Dr. Wheeler has recently given me two pairs of an interesting Microdon from Panama. The species is apparently new and a description follows.

\section{Microdon wheeleri, new species.}

Female. Length $8 \mathrm{~mm}$.

Form rather long and slender. Color testaceous, with the ocellar tubercle, pronotum, sides of vertex, metanotum and tip 
of abdomen strongly infuscated. Shining, coarsely and abundantly punctate. Everywhere with long golden-yellow semirecumbent pile, which at the anterior border of head is thicker and forms a brush.

Frons about twice as long as broad, broadest a little below antennal insertions, sides slightly convergent anteriorly, anterior border broadly concave. Vertex separated from frons by a very feeble transverse impression, strongly convex, at middle with a large, elongate tubercle bluntly projecting in front, bearing the ocelli. Eyes hairless. First antennal joint slender, as long as second and third together, second joint subcampanulate and about half as long as the third which is suboval and broadly rounded at apex; arista two-thirds as long as third joint. Antennal insertions enclosed by a circular elevated carina, which above projects horizontally and is angulately produced at middle. Scutellum broadly rounded at apex, excised at sides and bispinose, the anterior spine slender and acute, the posterior broad and truncate at tip. First abdominal segment twice as broad as the thorax, remainder of abdomen elongate and strongly narrowed apically. Posterior tibiæ at apex and the tarsi strongly incrassate, with a heavy brush of coarse, black setæ on outer border. Wings yellow, clouded apically, veins brown. Halteres yellow.

Male. Black, with black pilosity, except the terminal joint of antennæ, the frons, apical half of abdomen, front and middle tibiæ and all the tarsi, which are reddish brown, with yellow hairs.

Transverse impression between frons and vertex strongly impressed. Anterior border of frons narrowly and more deeply excised than in the female. Scutellum at sides with subequal spines on either side of the convexity.

Pupal case. Length 6.5-7 mm., width 2.75-3 mm.

Yellowish, transparent, not reticulate. Subcylindrical. Anterior spiracles slender, slightly arcuate, about as long as their distance apart at base, black in color, with coarse, unequal, fossulate punctures and, on apical third, several circular im- 
pressions. Posterior spiracle rugulose basally and rather strongly carinate.

Red Tank, Canal Zone, Panama. March 28, 1923.

Type and allotype-Cat. No. 26478, U. S. N. M.

Described from two females and two males, reared by Dr. Wheeler from pupæ collected in nests of Crematogaster (Orthocrema) brevispinosa Mayr. subsp. tumulifera Forel in Cordia alliodora Ruiz and Pavon.

The long and slender puparia, without reticulations and with their heavily fossulate anterior spiracles are very different from any other Microdon pupæ I have seen.

The adults are remarkable for their slender form, elongate front, the large ocellar tubercle and the laterally excised scutellum. The pile is unusually coarse, especially at the front of head and on the thorax, and is mostly a rich golden yellow. The coloration, as described for the female, may not be fully mature. Dr. Wheeler tells me that all the specimens were yellow at the time of emergence and darkened gradually.

III. BEES COLLECTED BY DR. W. M. WHEELER AT FLOWERS OF TRIPLARIS.

$$
\text { By T. D. A. Cockerell. }
$$

University of Colorado, Boulder, Colo.

The bees collected by Dr. Wheeler at Triplaris americana flowers in the Panama Canal Zone include seven species, which may be readily separated as follows:

Eyes hairy; three submarginal cells. .................

Eyes not hairy, two submarginal cells, or the second evanescent. 2

1. Abdomen mainly dark (Fort Clayton, Feb. 28, two workers at Triplaris).............. A pis mellifera Linnæus.

Abdomen with basal portion fulvous (Balboa, March 27, one worker at Triplaris). . Apis mellifera var. ligustica Spinola, 

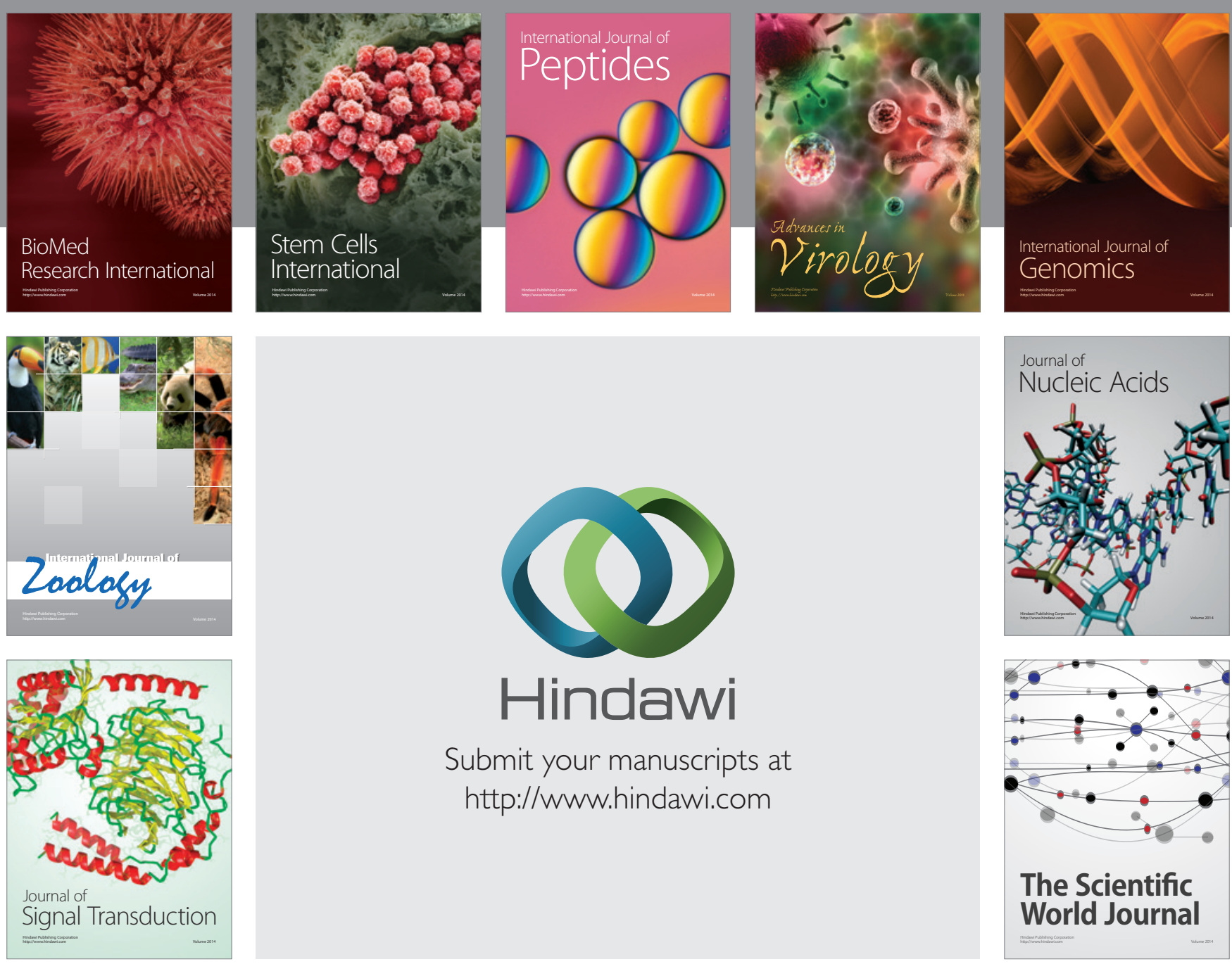

Submit your manuscripts at

http://www.hindawi.com
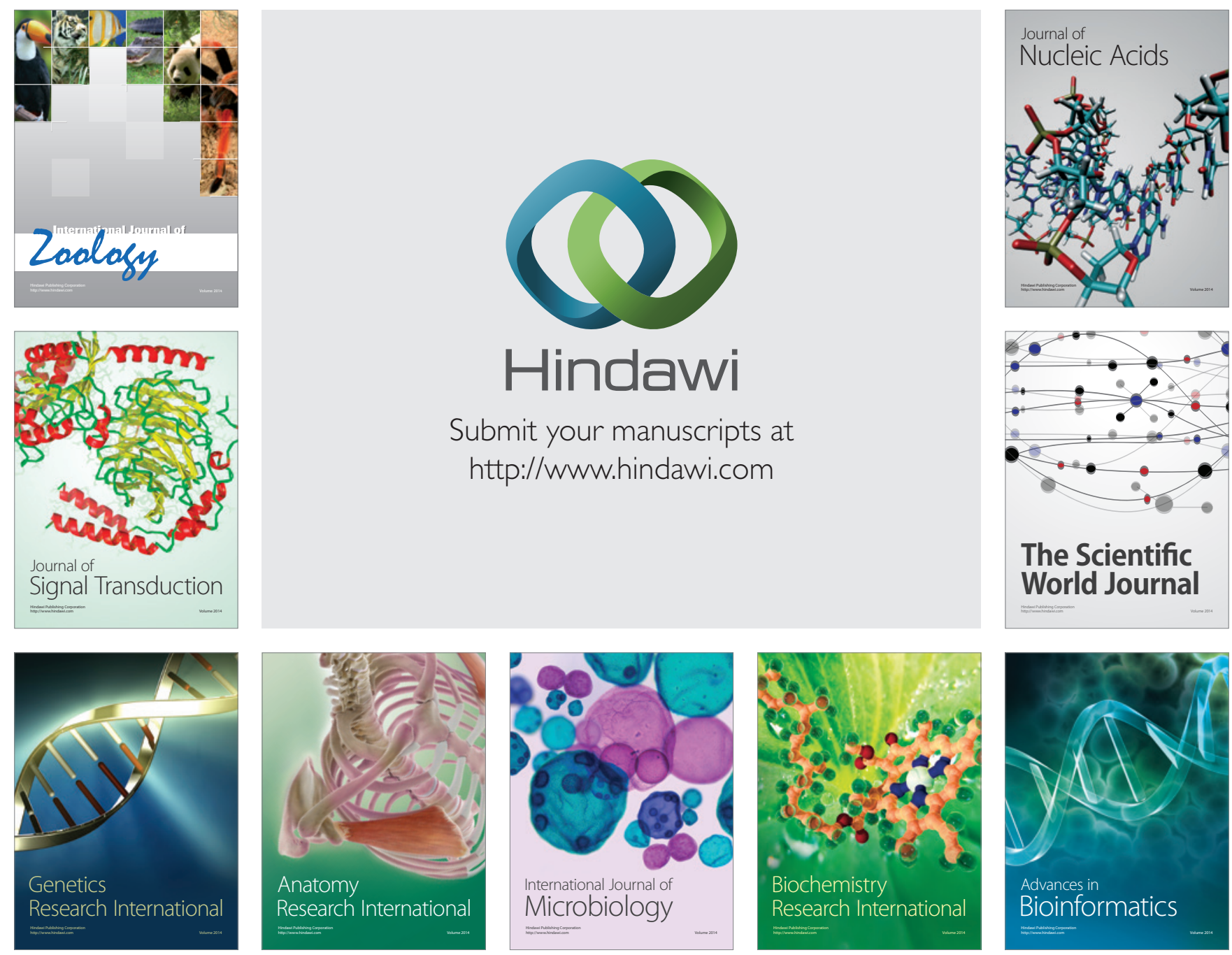

The Scientific World Journal
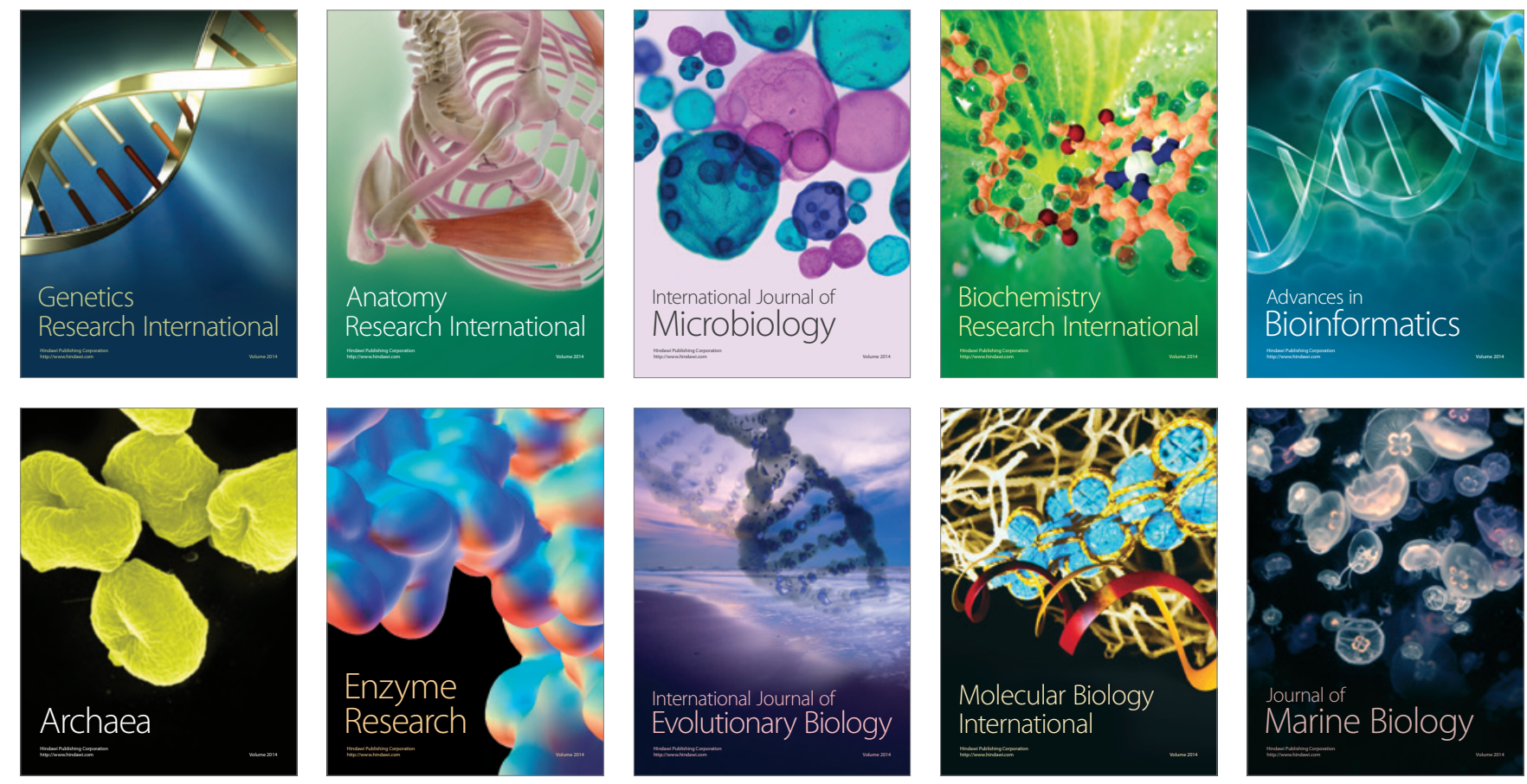